A Journal of Culture, English Language, Teaching \& Literature ISSN 1414-3320 (Print), ISSN 2502-4914 (Online)

$$
\text { Vol. } 18 \text { No.1; July } 2018
$$

Copyright (C) Soegijapranata Catholic University, Indonesia

An Error Analysis of Using Phrases in Writing Recount Text at Tenth Grade in SMA Parulian 2 Medan

${ }^{1}$ Gadis Selvia Sitorus, and ${ }^{2}$ Kammer Sipayung

${ }^{1,2}$ English Department, Teacher Training of Nommensen Medan, Medan, Indonesia

email: ${ }^{1}$ gadisselviasitorus14@gmail.com; ${ }^{2}$ ksipayung@yahoo.com

Received: 21-06-2016

Accepted: 25-06-2016

Published: 23-07-2018 


\title{
An Error Analysis of Using Phrases in Writing Recount Text at Tenth Grade in SMA Parulian 2 Medan
}

\author{
${ }^{1}$ Gadis Selvia Sitorus, and ${ }^{2}$ Kammer Sipayung \\ ${ }^{1}$ gadisselviasitorus14@gmail.com; ${ }^{2}$ ksipayung@yahoo.com \\ 1,2 English Department, Teacher Training of Nommensen \\ Medan, Medan, Indonesia
}

\begin{abstract}
This article deals with an error analysis of using phrases in writing recount text at tenth grader in SMA Parulian 2 Medan. The objective of the study is to identify the types of common phrases' error made by the students of tenth grader in SMA Parulian 2 Medan in writing recount text. This study used descriptive qualitative research. The subject of this study is the tenth grade students of SMA Parulian 2 Medan which consists of three classes. The object of this study is class of X-A. The instrument of collecting data used writing test, writing recount text. The data were analyzed by identifying the students' phrases errors by underlining each error from students' answer sheet, after that classifying the types of error based on five types of phrases. Finally, the research result showed that there are 145 phrases errors made by the students X-A in writing recount text. The types of phrases which indicate common error is on noun phrase. The number of noun phrase error are 83 with percentage $57,24 \%$, followed by verb phrase has 28 with percentage $19,31 \%$, the third is prepositional phrase which has 22 with percentage 15,17\%, the fourth is adjective phrase which has 10 with percentage $6,90 \%$, the last is adverb phrase has 2 with percentage 1,38\%. It was caused the students constructed or arranged the words or sentences based on Indonesian meaning. English has different rules in constructing phrases. The students also were lack of knowledge about phrases. Therefore, English teachers are expected to focus on types of phrases in learning English.
\end{abstract}

Key words: error analysis, error on phrases

Abstrak: Penelitian ini adalah merupakan studi tentang analisis kesalahan menggunakan frasa dalam menulis recount text di kelas $\chi$ di 
SMA Parulian 2 Medan. Tujuan dari penelitian ini adalah untuk mengidentifikasi jenis kesalahan frasa umum 'yang dibuat oleh siswa dari kelas X di SMA Parulian 2 Medan dalam menulis recount text. Penelitian ini menggunakan penelitian kualitatif deskriptif. Subjek penelitian ini adalah siswa kelas X SMA Parulian 2 Medan yang terdiri dari tiga kelas. Objek penelitian ini adalah kelas X-A. Instrumen pengumpulan data yang digunakan menulis tes, menulis recount text. Data dianalisis dengan mengidentifikasi siswa frase kesalahan dengan menggarisbawahi setiap kesalahan dari siswa lembar jawaban, setelah itu mengelompokkan jenis kesalahan berdasarkan lima jenis frase. Akhimya, Hasil penelitian menunjukkan bahwa ada 145 frase kesalahan yang dibuat oleh siswa X-A dalam recount text. jenis frase yang menunjukkan kesalahan umum adalah pada noun phrase. Jumlah kesalahan noun phrase ialah 83 dengan persentase 57,24\%, diikuti oleh verb phrase memiliki 28 kesalahan dengan persentase 19,31\%, yang ketiga adalah preposition phrase yang memiliki 22 kesalahan dengan persentase 15,17\%, yang keempat adalah adjective phrase yang memiliki 10 kesalahan dengan persentase 6,90\%, yang terakhir adalah adverb phrase memiliki 2 kesalahan dengan persentase 1,38\%. Hal ini disebabkan siswa membuat atau menyusun kata-kata atau kalimat berdasarkan makna bahasa Indonesia. Bahasa Inggris memiliki aturan yang berbeda dalam membangun frase. Para siswa juga kurang memiliki pengetahuan tentang frase. Oleh karena itu, guru bahasa Inggris diharapkan untuk fokus pada jenis frasa dalam belajar bahasa Inggris.

Kata kunci: analisis kesalahan, kesalahan pada frasa

\section{INTRODUCTION}

Language is a set of rule. Realization of rule can be recognized through grammar. Grammar is a set of structural rules that show how words are combined, arranged, or changed to give certain meaning. It is also basic elements of a language to build up sentences in expressing their ideas for communication activities. The grammar of foreign language is different with our mother language. Therefore, the students have to comprehend in learning the language skills (Speaking, Listening, Reading and Writing).

Writing is productive skill that students have to master. It is more complicated than other skills (speaking, reading and listening) in English. Writing relates with coherence, cohesion, diction, and grammar. As we know, grammar plays big role in producing writing text. We have to think how the readers can understand and comprehend what we write.Writing is a language 
skills by which students can express their ideas in written form. Writing is a complex process of decision making-of selecting, deleting, and rearranging material (Kirzner and Mandell, 2008, p. 29). It means that there are some steps to produce writing. It's not instant to do writing.

The students have the difficult to make sentences with good grammar. They usually make wrong organization and the placement every word in constructing phrases in sentences or paragraphs. In other hand, the students are lack to comprehend the using of English phrases. It makes the teacher confused to understand what the students mean in their writing. Based on explanation above, the writer would like to conduct a research entitled "An Error Analysis of Phrases in Writing Recount Text at Tenth Grade in SMA Parulian 2 Medan."

\section{REVIEW OF RELATED LITERATURE}

James (as cited in Bao, 2015) says that error analysis is the process of determining the incidence, nature, causes, and consequences of unsuccessful language. Error Analysis (EA) is the first approach to the study of Second Language Acquisition which includes an internal focus on learners' creative ability to construct language (Saville-Troike, 2006, p. 37). Error analysis is a method used to analyze error that appears in learning language. It means errors are not only in foreign language but also our mother tongue. The errors can be analyzed and observed to know what caused them.

Ellis (as cited in Krisnawati, 2013) states errors reflect gaps in a learner's knowledge; they occur because the learner does not know what is correct. Mistakes, on the other hand, reflect occasional lapses in performance because the learner is unable to perform what she knows. To know the distinguish by rechecking the mistake to the students, the students can recognize and correct the mistake that they have made. It is showed that the mistake that students have made is 'error in performance' or 'mistake'. But, if the students cannot recognize and correct the mistake that they have made, it means the mistake is 'error in competence' or 'error'.

\section{A. Types of errors}

According to Dulay, Burt, \& Krashen (1982, p. 146), the commonly used as bases for the descriptive classification of errors is linguistic category, surface category, comparative taxonomy, and communicative effect taxonomy. In surface category, errors are divided in four parts namely: 
82 Celt: A Journal of Culture, English Language Teaching \& Literature, Volume 18, Number 1, July 2018, pp. 79 - 88

1. Omission error is characterized by omitting of an item that should appear in a well-formed utterance. For example: She walks the street (Dia berjalan di jalan).

2. Additions error is the presence of an item which should not appear in well-formed utterances. Addition are divided three parts : a) Double marking is the failure to delete certain items which are required in some linguistics contraction but not in others. For example, "She doesn't works". b) Regularization is those in which a marker that is typically added to a linguistic item is erroneously added to exceptions that can be found in English. For example, the verb eat cannot be changed into eated but ate. c) Simpe addition is if an addition error is neither a double marking nor regularization. For example: I want a that bag.

3. Misformation error is characterized by using of the wrong form of the structure. For example, "The man went on bus". 4) Misordering error is the incorrect placement of a morpheme or group morphemes in an utterance. For example, "He is boy handsome".

\section{B. Sources of errors}

There are source of errors (Brown, 2007, p. 263):

1. Interlingual transfer

Interlingual errors may occur at different level such as transfer of phonological, morphological, grammatical and lexica-semantic elements of the native language into the target language (cited in Ratnah, 2013, p. 161).

\section{Intralingual transfer}

Intralingual errors result from faulty or partial learning of the target language rather than language transfer.

\section{Writing}

Writing is a complex process of decision making-of selecting, deleting, and rearranging material.writing is the process of using vocabulary, spelling, symbols, sentence to communicate ideas or thoughts in a readable form though many steps to produce good writing (Kirszner and Mandell, 2008, p. 29). There are six stages in the process of writing, they are: planning, shaping, drafting, revising, editing and proofreading. 


\section{Recount text}

Recounts are the simplest text type in this genre (Knapp, 2005, p. 223). Formally, recounts are sequential texts that do little more than sequence a series of events. Recount is one of text that functions to tell what happen in the past to their audience.

\section{E. Phrases}

A phrase is a group of words forming a unit and united around a head, e.g. a noun or a verb (Gelderen, 2010, p. 45). Murdibjo \& Murdibjo in Prihandini (2011) describes phrase is a group of words, which has a unit of definition, but it cannot be a complete sentence. Phrase cannot stand alone (dependent). Phrase can put as subject or object in the sentence. We can conclude that phrase is a substance to construct the sentence. There are five types of phrases or group (Knapp and Watkins, 2005, p. 60):

\section{Noun phrase}

Noun phrase has a noun as headword. Headword can be noun or pronoun. There are some constructions of Noun Phrase in English: determiner, pre modifier (modifier before noun), post modifier (modifier after noun) and the combination of them.

a) Determiner + Noun, for example: (i) My bag: Possesive +Noun, (ii) An apple: Article + Noun, (ii) That book: Demonstrative + Noun

b) Pre modifier (modifier before noun such as: determiner, adjective, participle or others noun). For example: (i) My beautiful girl, (ii) A love letter

c) Post Modifier (modifier after noun such as prepositional phrase, Wh-clauses, participial phrase). For example: (i) The book on the table, (ii) The city where I was born

d) The combination of determiner, pre modifier and post modifier. For example: (i) My cute cat stole the fish on the table, (ii) The handsome man give me the dark chocolate.

\section{Verb phrase}

A verb phrase consists of main verb and one or more auxiliaries (Martin, 1984, p. 144). The main verb can be either action verb or a linking verb. 
84 Celt: A Journal of Culture, English Language Teaching \& Literature, Volume 18, Number 1, July 2018, pp. 79 - 88

For example: (i) I have finished my Biology task, (ii) She is cooking the noodle.

\section{Adjective Phrase}

Adjective phrase has an adjective headword. Adjective phrase can be used an attributive or a predicative adjective.

a) Attributive adjective

An attributive adjective is adjective that puts before the noun or inside the noun phrase. For example: The old man is sitting in the park

b) Predicative adjective

A predicative adjective is adjective that puts after the noun or outside the noun phrase. For example: The building looks high.

4. Adverbial phrase

Adverbial phrase has an adverb as their headword. It has function like an adverb to modify a verb, an adjective or another adverb. It itself are (optionally) accompanied by a degree marker such as very, too, extremely, really. For examples:

i) She runs very fast. (modifies verb run)

ii) He always sings in loud voice. (modifies verb sing)

5. Prepositional Phrase

A prepositional phrase consists of a preposition (a word such as on, to,in, or with) and its object (the noun or pronoun it introduces) Kirszner and Mandell, 2009, p. 248). For example:

\begin{tabular}{|c|c|c|c|}
\hline Preposition & + & Object & $=$ Prepositional Phrase \\
\hline On & & the street & on the street \\
\hline to & & Siska's room & to Siska's room \\
\hline in & & her red wallet & in her red wallet \\
\hline
\end{tabular}




\section{METHODOLOGY}

This research is descriptive qualitative method to analyze phrases errors in writing. Descriptive qualititative refers to human phenomenon or behavior that happen naturally. Subject of this research is the students of tenth grade in SMA Parulian 2 Medan in the academic year 2015/2016, especially in class of X-A. There are three parallel classes and each class consists of 35 students.

This research uses writing test, writing recount text to test the students' ability in analyzing phrases errors in recount text. In analyzing collected the data, the writer (1) identify all the types of phrases' errors by underline the words in students' sheet based on the types of errors namely; errors of omission, errors of omission, errors of addition, errors of misformation, and errors of misordering, (2) count the number types of phrases' errors which students used in writing recount text, and (3) convert the frequency types of phrases' errors percent by following formula based on Sudijono (2014, p. 43):

$$
\begin{array}{ll}
X=\frac{F}{N} \times & 100 \% \\
\mathrm{X} & =\text { The percentage type of phrases' error } \\
\mathrm{F} & =\text { Frequency type of phrases' error } \\
\mathrm{N} & =\text { Total number of phrases' error } \\
100 \% & =\text { Standard Percentage }
\end{array}
$$

\section{RESULT OF THE STUDY}

After analyzing and counting phrases' error from students' answer sheet, the writer shows the list of the percentage of phrases' errors in writing recount text. It can be seen on the figure 1 . Based on the figure, the total of phrases error are 145. The number of noun phrase errors is 83 and the percentage is $57.24 \%$.

The number of noun phrases included errors of omission are 28 and the percentage is $33.74 \%$, errors of addition are 3 and the percentage is $3.61 \%$, errors of misformation are 23 and the percentage is $27.71 \%$ and errors of misordering are 29 and the percentage is $34.94 \%$.

The number of verb phrase errors is 28 and the percentage is $19.31 \%$. The number of verb phrase includes the errors of omission are 1 and the percentage is $3.57 \%$, errors of addition are 18 and the percentage $64.29 \%$, 
Celt: A Journal of Culture, English Language Teaching \& Literature, Volume 18, Number 1, July 2018, pp. 79 - 88

errors of misformation are 9 and the percentage is $32.14 \%$ and there is none of error of misordering.

\section{Figure 1:}

\section{Percentage of phrases errors in writing recount text}

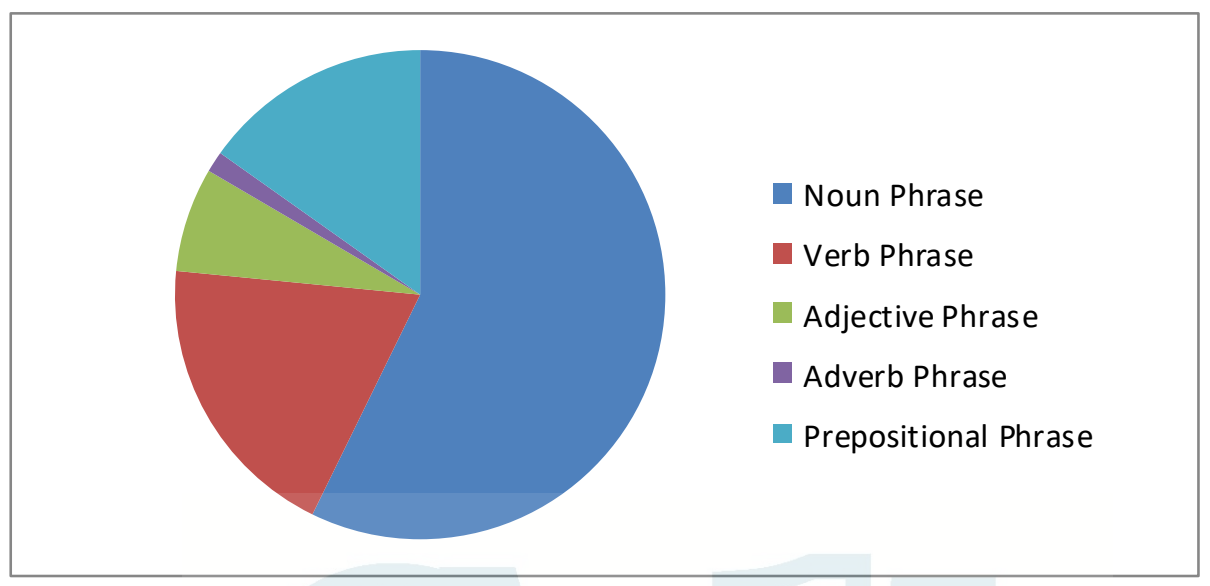

The number of adjective phrase errors is 10 and the percentage is $6.90 \%$. It is only an error for misordering. There are no errors of omission, addition and misformation.

The number of adverb phrase error is 2 and the percentage is $1,38 \%$. It is only having error of addition and there is none of error of omission, misformation and misordering.

The number of prepositional phrase is 22 and the percentage is $15.17 \%$. The number of prepositional phrase included errors of omission is 8 and the percentage is $36.36 \%$, errors of addition are 2 and the percentage is $9.09 \%$, errors of misformation are 12 and the percentage is $54.55 \%$ and there is none of error of misordering.

The highest number of errors on noun phrase is with the percentage $57.24 \%$. It was common errors of phrase made by the students X-A. The second place is verb phrase with the percentage $20,74 \%$, in the third is prepositional phrase with $16.30 \%$, in the fourth place is adjective phrase with percentage $2.96 \%$ and the last is adverb phrase with percentage $1,48 \%$. The error of misformation was common error from four types of error which occurred in using phrases in writing recount text. It was caused by the students who were lacking to comprehend the constructing phrases in sentences or paragraphs. The students just learnt about using articles and they do not know 
that it is part of the noun phrase. They did not have knowledge about the phrase and its parts. Therefore, the students made errors in using the phrases.

\section{CONCLUSION AND SUGGESTION}

The study reveals that the students made many phrases errors in writing recount text. The total number of phrases errors are 145 from all types of phrases available. It means that the teacher should pay attention about this problem. Noun phrase becomes the type common phrase error made by the students because the students lack comprehension in using the phrase.

For this reason, a number of suggestions are as follows:

1. The teacher has to make learning phrases become interesting. They should make phrases understood to students because a phrase is useful for students' skills.

2. The students are expected to pay attention when learning English especially about phrases. The students have to learn about phrases in detail because it is useful for their skill to not only master it in writing but also in other skills (ie. speaking, reading and listening).

3. The writer also suggests to the writers of Grammar books to write and arrange English material especially about types of phrases in more detail in order to enrich knowledge how to use types of phrases well.

4. Other researchers are suggested to explore and develop another study about phrase. It is useful to make more knowledge about phrases in order that people can understand better in using the phrases.

\section{REFERENCES}

Bao, X. (2015). Senior High School Students' Errors on the Use of Relative Words. English Language Teaching, 8(3), 137-154.

Brown, H.G. 2007. Principle of Language Learning and Teaching ( $5^{\text {th }}$ ed.). New York: Pearson Education,Inc.

Dulay, H., Burt, M., \& Krashen, S. (1982). Language Two. New York: Oxford University. 
Gelderen, V. E. (2010). An introduction to the grammar of English (Revised ed.). Amsterdam: John Benjamins Publishing.

Patel, M. F., \& Jain, P. M. (2008). English language teaching. Sunrise Publishers and Distributors.

Krisnawati, E. (2013). Error or mistake? Incorrectness in students' answers in a subject-matter examination. International Journal of Language Learning and Applied Linguistics World, 4, 1-16.

Kirszner, L. G., \& Mandell, S. R. (2011). Writing first with readings: Practice in context. London: Macmillan.

Knapp, P., \& Watkins, M. (2005). Genre, text, grammar: Technologies for teaching and assessing writing. Sidney: UNSW Press.

Martin, J. (1984). Health English. Lexington: D.C. Health and Company.

Mehler, A., Sharoff, S., \& Santini, M. (Eds.). (2010). Genres on the web: Computational models and empirical studies (Vol. 42). London, New York: Springer Science \& Business Media.

Pardiyono, M. P. (2007). Pasti bisa! Teaching genre-based writing [You can do it! Teaching genre-based writing]. Yogyakarta: Penerbit Andi.

Prihandini, A. (2011). The analysis of function, category and role in English Headlines. Journal of Language Science, 6, 1-21.

Ratnah. (2013). Error analysis on tenses usage made by Indonesian students. Journal of Education and Practice. Makassar Tourism Academy, 6, 159-169.

Saville-Troike, M., \& Barto, K. (2016). Introducing second language acquisition. Cambridge University Press. 